\title{
Ecotourism and Sustainable Development of Mountain Communities: A Study of Dhanolti Ecopark in Uttarakhand State of India
}

\author{
Chandra Prakash Kala* \\ Ecosystem and Environment Management, Indian Institute of Forest Management, Nehru Nagar, Bhopal, Madhya Pradesh, India \\ *Corresponding author: cpkala@yahoo.co.uk
}

Received October 03, 2013; Revised October 21, 2013; Accepted October 21, 2013

\begin{abstract}
The value of ecotourism in creating opportunities for sustainable development of communities and management of ecosystem and environment was studied in the Uttarakhand state of India. This Himalayan state promotes ecotourism in national parks and sanctuaries, apart from exclusive areas created for ecotourism in the form of ecoparks. One such ecopark namely Dhanolti ecopark was surveyed intensively, which is jointly managed by the state forest department and the local communities. The ecopark's income has continuously increased since its inception and the participatory management practices have also improved its ecosystem and surrounding environmental conditions. The area that was once degraded due to dumping of non-degradable plastic waste is now almost free from such environmental-unfriendly substances. The study further argues that which model is more appropriate for meeting the requirement of ecotourism; whether the national park and sanctuary or the ecopark.
\end{abstract}

Keywords: ecotourism, ecosystem management, sustainable development, Uttarakhand, national park, ecopark

Cite This Article: Chandra Prakash Kala, "Ecotourism and Sustainable Development of Mountain Communities: A Study of Dhanolti Ecopark in Uttarakhand State of India.” Applied Ecology and Environmental Sciences 1, no. 5 (2013): 98-103. doi: 10.12691/aees-1-5-5.

\section{Introduction}

Natural areas with rich biodiversity and scenic beauty, such as the Himalayas, have been the major destination centers for nature lovers from historical time. With the passage of time, the heavy influx of unregulated tourism and its activities, however, have mounted unprecedented pressures on such areas of tourist's attractions in terms of loss of native biodiversity and degradation of ecosystems and environment [1,2]. The continuous degradation of such ecosystems and the loss of services supplied by them have evoked the need of sustainable development of tourism centric places all over the world. According to the United Nations World Tourism Organization (UNWTO), sustainability principles refer to the environmental, socioeconomic and socio-cultural aspects of tourism development along with creating suitable balance between these three dimensions.

The concept of sustainable tourism has given birth to a quite popular and acceptable term 'ecotourism', which indicates the responsible travel to natural areas that conserves the environment and improves well-being of local inhabitants. The practice of ecotourism or sustainable tourism is known to have the potential of helping the conservation of natural areas in such a way so that the local communities may be benefited by improving their living standards without slowing down their age-old traditions and cultures [3,4,5,6,7]. Ecotourism is being defined in different ways by different groups of people [8] On one hand the scenic beauty of natural areas attracts large number of tourists, while on other hand many conservationists wish to regulate the flow of tourists and advocate implementation of existing conservation practices, especially in the environmentally sensitive areas $[8,9,10]$.

Recently in 2013, the UNWTO has given the node to adopt the resolution which recognized ecotourism as a key to fight against poverty, the protection of the environment and the promotion of sustainable development under the title 'Promotion of ecotourism for poverty eradication and environment protection'. The recognition of ecotourism in creating opportunities for the conservation, protection and sustainable use of biodiversity and of natural areas by encouraging local and indigenous communities is a known fact, at present, which is supported widely. This fact encourages Member States to promote investment in ecotourism, in accordance with their national legislation, including creating small and medium-sized enterprises and cooperatives such as microcredit initiatives for the poor, local and indigenous communities, in areas of ecotourism potential and rural areas [11].

In view of the importance of ecotourism, the Government of India prepared a detailed set of guidelines on the selection, planning, development, implementation and monitoring of ecotourism in India. These directives and guidelines are applicable to all Protected Areas, including national parks, wildlife sanctuaries, sacred groves, or pilgrimage spots within protected areas and 
forested areas. The guidelines intend to adopt low-impact tourism that protects ecological values of the destination and its surrounding areas, including building up environmental and cultural awareness, facilitating sustainability of ecotourism enterprises and activities, providing livelihood opportunities to local communities, and to use indigenous, locally produced and ecologically sustainable materials for tourism activities [12]. Realizing the diverse natural areas in the country, the responsibility to develop state-specific ecotourism plans are dispensed to the respective State Governments.

Uttarakhand is one of the Indian states, lies in the Himalayas, and is well known for its rich biodiversity, scenic beauty and tourist destination $[13,14,15,16,17]$. The Government of Uttarakhand promotes eco-tourism through its eco-tourism wing which is created to promote eco-tourism activities, especially in the forest areas of the state. The eco-tourism wing seeks to draft policies and provide funds for various eco-tourism projects and provide a framework for the promotion and development of eco-tourism in the state. The state has developed ecotourism areas in the national parks, sanctuaries and in forest areas. An eco-park has been developed in the hills of Uttarakhand under the banner of Dhanolti Ecology and Ecotourism Development Committee, which is commonly known as Dhanolti Eco-park. This eco-park has been selected as an example for studying various issues of ecotourism, its pros and cons and the avenues of developing appropriate strategies for promotion of ecotourism in the state. The study further discusses that which model of ecotourism, whether the national park and sanctuary or the ecopark, is more appropriate for meeting the requirement of ecotourism as chalked out by the UNWTO and the state government.

\section{Methods}

Dhanolti ecopark of Uttarakhand state in India was studied intensively and surveyed for collection of data on the yearly arrival of number of visitors and income generated by providing required facilities to the visitors and also conducting various activities in the ecopark. The ecopark authorities and employees were interviewed for the collection of information on the benefit sharing mechanism and employment generation after establishing ecopark. The official records of Dhanolti ecopark on various expenditures for developing and maintaining ecopark along with various sources of ecopark income, as maintained by Dhanolti Ecology and Ecotourism Development Committee (DEEDC), were also examined. The waste disposal mechanism of DEEDC was scrutinized. The collected information on the number of tourists and income generation at the ecopark was compared with the similar information available for the national parks and sanctuaries within the state of Uttarakhand.

\section{Results and Discussion}

\subsection{Dhanolti Eco Park}

In view of the wide recognition of ecotourism in the natural areas and also to fight against poverty, apart from protection of environment and promotion of sustainable development, the state government of Uttarakhand in India has established an ecopark in Dhanolti - a small hill station. The Dhanolti ecopark is $30 \mathrm{~km}$ away from Mussoorie town and $63 \mathrm{~km}$ away from Dehradun - the capital city of Uttarakhand. The ecopark is situated at an altitude of $2280 \mathrm{~m}$ a.m.s.l. between $30^{\circ} 42^{\prime} \mathrm{N}, 78^{\circ} 24^{\prime} \mathrm{E}$.

Before setting up the ecopark, the villagers in and around Dhanolti town were approached by the state forest department, and a series of consultative meetings were held with them on the prospects of developing an ecopark at Dhanolti. The numbers of problems of the villagers were identified during the consultative meetings. Unemployment was one of the major problems, which had forced local youths to migrate from their villages to cities in search of employment and better opportunities, especially to Dehradun and New Delhi.

The lack of knowledge and less-informed tourists and locals used to through garbage frequently in the surrounding deodar forest, which polluted the ecosystem and environment of this hilly region. Trespassing in reserve forest by hoteliers and locals were a matter of grave concern for forest department in order to manage the existing forests mainly composed of deodar, rhododendrons and oaks.

To mitigate pressure on the forest ecosystem, and at the same time to provide some employment to the local people apart from ascertaining their participation in the management of forest and ecosystem, the consensus emerged on developing an ecopark at Dhanolti. A committee was formed naming Dhanolti Ecology and Ecotourism Development Committee (DEEDC), which was registered in 2008 under the Society Registration Act 1860. The place, as offers a panoramic view of the Himalayas and magnificent deodar forests, the ecopark was finally established in about 13 ha of reserve forest chiefly dominated by deodar trees. The ecopark declared open for public and tourism activities were initiated here from June 2008.

\subsection{Management of Ecopark}

Dhanolti ecopark is managed by a committee of 18 members, including 3 members from woman folks. The main role of DEEDC is to manage the ecopark, conserve forest and ecosystem, dispose off and recycle garbage, and collect fees for various amenities, as provided to the tourists. Besides, the committee looks after the conservation and management of adjoining forest areas. The five major amenities provided by ecopark to the visitors are: accommodation facility in eco-huts, amusement facilities like flying fox and burma bridge, plantation of memory saplings, nature trails with yoga centre and a interpretation centre.

Eco-huts are made up of bamboo and are rented to visitors for night stay on some nominal charges (Figure 1). The adventure sports facility is available for visitors in the form of walking over the flying fox and burma bridges and riding horses. There is also a facility for visitors to plant a sapling of tree species in the memory of their beloved, which is called as memory sapling plantation. There is a Yoga centre in the ecopark's premises, which disseminate the power of Yoga to maintain health and keep one's body away from diseases. Besides, there is an interpretation centre which helps to generate awareness on 
the conservation and management of the Himalayan ecosystem and biodiversity. Some local handicraft items are also available in the ecopark to visitors for purchase.

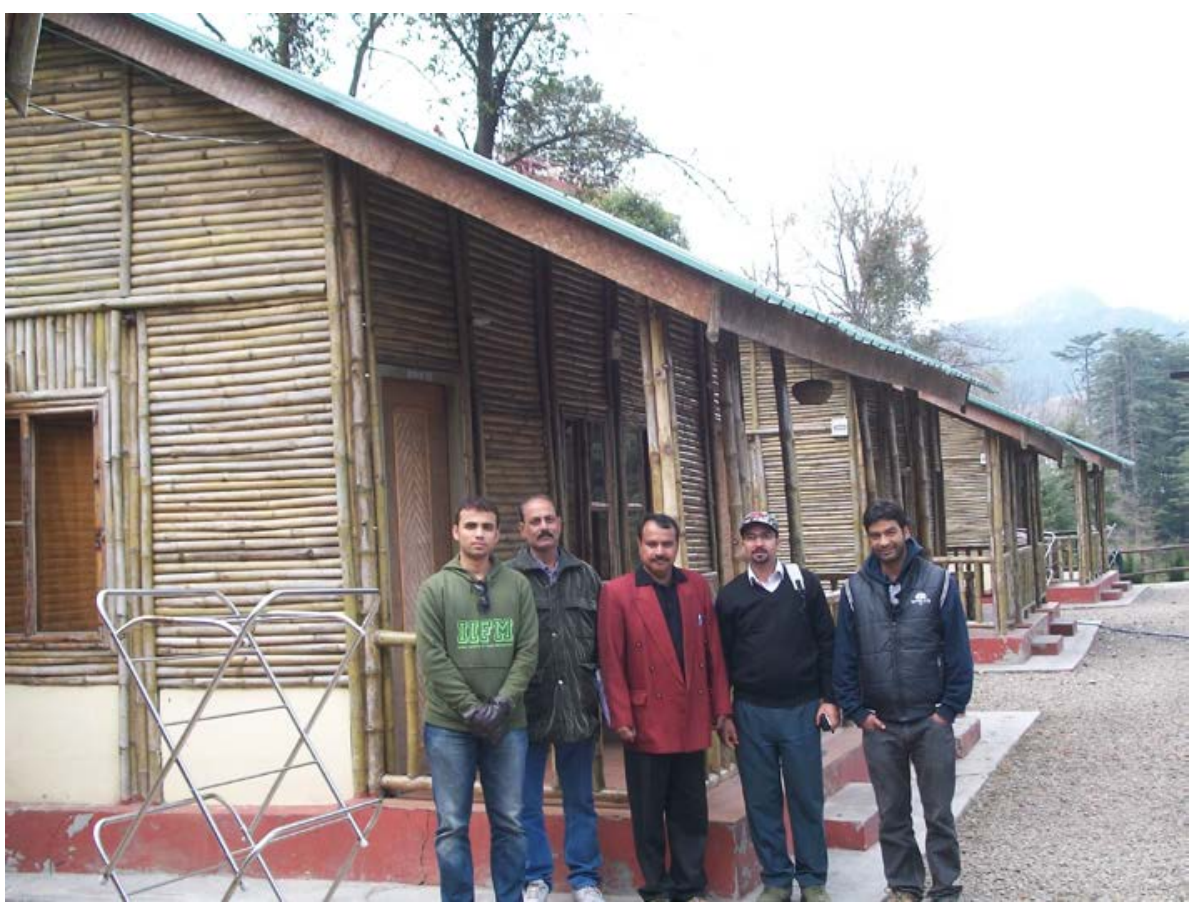

Figure 1. An income generation source - the attractive bamboo huts - in Dhanolti ecopark of Uttarakhand state, India

\subsection{Income Sources of Ecopark}

There are different sources of income. The ecopark is divided into two major parts - the upper one is called as Ambar (sky) and the lower one is Dhara (earth). The visitors pay some nominal entry fees, which varies from Rs. 20 per adult [56 Rs. = 1 US \$] to Rs. 10 per kid for visiting Ambar and Rs. 15 per adult to Rs. 10 per kid for visiting Dhara. Per night stay charge in the bamboo hut is Rs. 1500. The charge for enjoying a walk over the Burma bridge is Rs. 20 per person and the charge for sliding on the flying fox is Rs. 50 per person. The cost of memory sapling plantation is Rs. 350.

Table 1. Expenditure in developing eco-park Dhanoulti and subsequent income generated

\begin{tabular}{|c|c|c|c|c|c|}
\hline \multirow[b]{2}{*}{ Year } & \multirow{2}{*}{$\begin{array}{c}\text { Total } \\
\text { expenditure } \\
\text { (in Rs. )* }\end{array}$} & \multirow{2}{*}{$\begin{array}{l}\text { No. of } \\
\text { visitors }\end{array}$} & \multicolumn{2}{|c|}{ Income generated } & \multirow{2}{*}{$\begin{array}{c}\text { Total } \\
\text { income } \\
\text { generated } \\
\text { (in Rs.) }\end{array}$} \\
\hline & & & $\begin{array}{c}\text { Bamboo } \\
\text { huts }\end{array}$ & $\begin{array}{c}\text { Park } \\
\text { activities }\end{array}$ & \\
\hline $\begin{array}{c}2008- \\
09\end{array}$ & 9602600 & 43281 & 0 & 538660 & 538660 \\
\hline $\begin{array}{c}2009- \\
10 \\
\end{array}$ & 2231797 & 114154 & 87785 & 1615131 & 1702916 \\
\hline $\begin{array}{c}2010- \\
11 \\
\end{array}$ & 750000 & 107350 & 621811 & 2112749 & 2734560 \\
\hline $\begin{array}{l}2011- \\
12 \\
\end{array}$ & 464000 & 119745 & 699747 & 2614951 & 3314698 \\
\hline Total & 13048397 & 384530 & 1409343 & 6881491 & 8290834 \\
\hline
\end{tabular}

*One US \$ = 56 Rs. as on June 2012

The ecopark income has continuously increased since its inception in 2008 from Rs. 5,38,660 to Rs. 33,14,698 in 2012, which is over 6 times higher (Table 1). Over the period of four years the ecopark has generated a total Rs. $82,90,834$. Of this income $83 \%$ is gained by conducting various activities in the ecopark and remaining $17 \%$ is contributed by providing accommodation in the eco-huts. Eco-huts were made functional in 2009, and since then the income generation from these eco-huts has continuously increased, as they provide the pleasure of living in huts and the scenic beauty, as well. In the initial stage of establishing ecopark the expenditure was naturally higher for developing infrastructure, which is declined over the years.

Table 2. Non-biodegradable waste disposal from the ecopark

\begin{tabular}{|c|c|}
\hline Year & Waste disposal (in kg) \\
\hline $08-09$ & 2040 \\
\hline $09-10$ & 951 \\
\hline $10-11$ & 910 \\
\hline $11-12$ & 210 \\
\hline
\end{tabular}

\subsection{Ecosystem and Environment Management}

The approach of participatory conservation through DEEDC has improved the ecosystem and environment conditions of Dhanolti. The area which was once degraded due to dumping of non-degradable plastic waste is now almost free from such non-biodegradable substances. The use of such wastes has declined over the years and so that the quantity of its disposal has reduced (Table 2). DEEDC has placed holdings on the road and vantage points depicting the ill effects of non-biodegradable substances and other garbage, which help in spreading awareness among the tourists and locals to use dustbins rather than littering anywhere in nature. The waste is gathered and transported to the nearest city, Dehradun, where it is recycled or dispose off properly. The reduction in garbage has helped the local flora to revive. In addition, over 1000 saplings of tree species, mainly of deodar, have been planted as memory plantations in the ecopark area. These saplings flourish well, as they all are under intensive care of the DEEDC. The encroachment activities have also been minimized. 


\subsection{Benefit Sharing and Livelihood Generation}

The total income as generated by conducting different activities in the ecopark is shared in such a way so that the ecopark can be made functional besides providing benefits to the local people. Of the total ecopark income, the maximum share $(40 \%)$ is provided as honorarium to the local people for conducting various activities in the ecopark and environmental conservation. Thirty percent of ecopark income is used for the maintenance and development of ecopark. Twenty percent is allotted as revenue in state exchequer, and remaining $10 \%$ of total ecopark income is deposited in the corpus fund.

The ecopark provides regular employment to 25 local youths, including 3 women. Various park activities and increase in tourist's influx have enhanced livelihood opportunities to many other local people who are not regular employees of ecopark such as, local mule owners, photographers, small shopkeepers, hoteliers, restaurant owners, porters, vendors, including local farmers producing seasonal vegetables and fruits etc.

\subsection{Sustainable Mountain Development}

Dhanaulti eco-park contributes considerably to establish the concept of eco-tourism as a tool for sustainable development of communities along with nature and natural resources. The well designed mandate of this ecopark ensures participation and engagement of local communities in conservation and management of ecosystem and environment. It further helps to create awareness in masses about the conservation of biodiversity and natural resources by synchronizing these valuable assets with the livelihood of local people (Figure 2).

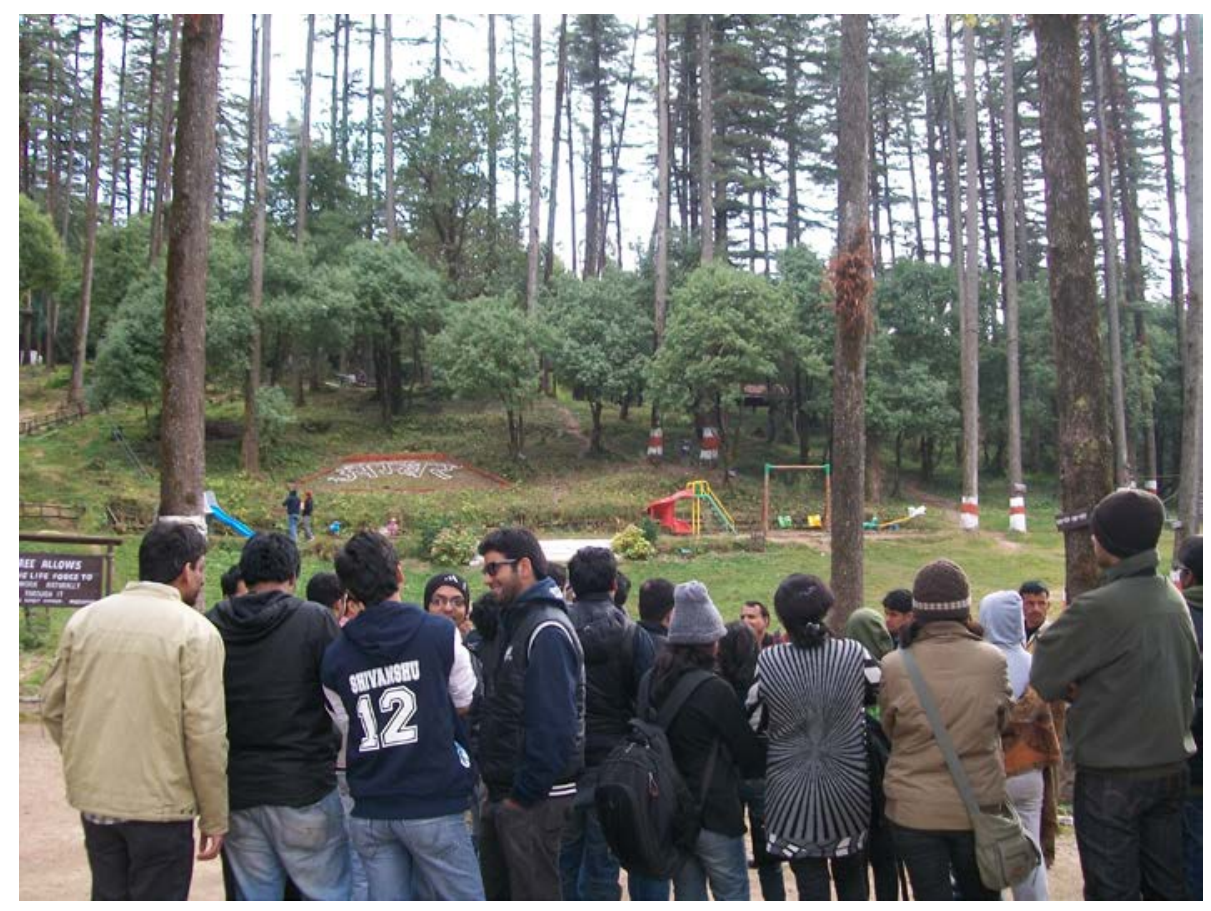

Figure 2. Sharing of experiences with the post graduate students by Dhanaulti Ecology and Ecotourism Development Committee members on the management of Himalayan ecosystem and environment

Table 3. Status of national park and sanctuaries in Uttarakhand state of India (One US \$ = 56 Rs. as on June 2012)

\begin{tabular}{|c|c|c|c|c|}
\hline Name of protected area & $\begin{array}{c}\text { Year of } \\
\text { establishment }\end{array}$ & $\begin{array}{c}\text { Area (in square } \\
\text { km) }\end{array}$ & $\begin{array}{c}\text { Number of } \\
\text { tourists }\end{array}$ & $\begin{array}{c}\text { Total revenue generated (Rs. in } \\
\text { lakhs) }\end{array}$ \\
\hline Corbett National Park & 1936 & 520.82 & 210262 & 719.38 \\
\hline Rajaji National Park & 1983 & 620.42 & 21061 & 52.42 \\
\hline Gangotri National Park & 1989 & 2390.02 & 15367 & 38.15 \\
\hline Valley of Flowers National Park & 1982 & 87.50 & 6855 & 11.39 \\
\hline Nanda Devi National Park & 1982 & 624.60 & 63 & \multirow{2}{*}{4} \\
\hline Govind National Park & 1990 & 472.08 & 2297 & \multirow{2}{*}{3} \\
\hline Govind Pashu Vihar Wildlife Sanctuary & 1955 & 485.89 & 17.57 \\
\hline Binsar Wildlife Sanctuary & 1988 & 45.59 & 17111 & 29.41 \\
\hline Sonanadi Wildlife Sanctuary & 1987 & 301.18 & 803 & 1.31 \\
\hline Kedarnath Wildlife Sanctuary & 1972 & 975.20 & Data not available \\
\hline Ashkot Musk Deer WLS & 1986 & 599.93 & Data not available & Data not available \\
\hline Mussoorie WLS & 1993 & 10.82 & Data not available & $\mathbf{8 9 4 . 6 4}$ \\
\hline
\end{tabular}




\subsection{Comparison of Dhanolti Ecopark with other Ecotourism Sites}

Uttarakhand being a Himalayan state that harbours rich biodiversity and breathtaking landscape beauty, as per the Wildlife Protection Act 1972 a total 12 protected areas have been set aside along the width and breadth of the state covering various ecosystems, forest types and landscapes [18]. The reasons of creating these protected areas include the purpose of protecting, propagating or developing biodiversity and maintaining ecological and geomorpholocal values of the areas declared as a national park or sanctuary. Half of these total protected areas are national parks and half of the protected areas are wildlife sanctuaries (Table 3). These protected areas altogether cover $13.95 \%$ of the state's total geographical area.

The history of protection differs across the protected areas and the Corbett National Park being the oldest protected area in India still boasts high biodiversity including tiger and hence attracts tourists from far and wide. Within a year, from April 2011 to March 2012, a total 2,91,954 tourists paid their visit to 10 protected areas of Uttarakhand out of total 12 existing protected areas (excluding Ashkot and Mussoorie Wildlife Sanctuary as data were not available for these two). Within one year period, these protected areas altogether generated Rs. 894.64 lakhs revenue, of which the Corbett National Park alone contributed Rs. 719.38 lakhs, which forms $80 \%$ of the total revenue generated by all 10 protected areas.

In one year, from April 2011-March 2012, Dhanolti ecopark, which spans over 13 ha of land, was visited by 26,14,951 tourists. In a year the ecopark earned Rs. 33, 14,698 revenue, which is higher than the revenue earned by 6 important national parks and sanctuaries such as the Valley of Flowers National Park, Nanda Devi National Park, Govind National Park, Govind Wildlife Sanctuary, Sonanadi Wildlife Sanctuary and Kedarnath Wildlife Sanctuary. The Nanda Devi National Park may be excluded from this comparison to Dhanolti ecopark, as there are restrictions on tourism in this national park, and also the park remains under snow for major part of the year.

Table 4. The trends in number of visitors to the Corbett National Park and Dhanolti ecopark

\begin{tabular}{|c|c|c|}
\hline \multirow{2}{*}{ Year } & \multicolumn{2}{|c|}{ Number of Tourists } \\
\cline { 2 - 3 } & Corbett National Park & Dhanolti Ecopark \\
\hline $2008-09$ & 221,083 & 43281 \\
\hline $2009-10$ & 223,761 & 114154 \\
\hline $2010-11$ & 189,793 & 107350 \\
\hline $2011-12$ & 210,612 & 119745 \\
\hline
\end{tabular}

The number of visitors to the Corbett National Park shows some declining trend from 2008-09 to 2010-11. Interestingly, there was a marginal fall in the number of tourists to Dhanolti ecopark in the same year (2010-11); nonetheless the visitor's number shows continuous increase in the ecopark, since its inception in 2008 (Table 4). The yearly proportion of visitors to the Corbett National Park and the Dhanolti ecopark is almost similar. There are some points, which go in favor of better ecotourism prospects in the model of Dhanolti ecopark. It is a newly established ecopark, spans over a small area, and even not advertized properly within the country. Despite several such limitations, the park has attracted a large number of visitors and has got considerable recognition within past four years.

Dhanolti ecopark, as an example, indicates tourist's attractions in community managed ecotourism. In addition, local support is required for biodiversity conservation and ecosystem management by combining co-ownership and co-management, as reflected by a long-term study conducted in the neighboring country of Nepal by Bookbinder et al. [19]. Further, the community-based tourism can foster changes in local attitudes toward forest and wildlife, as ecotourism encourages local guardianship of resources. Dhanolti model of ecotourism is expected to sensitize masses for coming forward seriously for the conservation of biodiversity and ecosystem. The need of the hour is therefore to develop responsible eco-tourism based on thoroughly thought and rigorously applied rules and regulations.

It is a subject of debate whether the protected areas, especially the national park, should be opened for ecotourism or they should be closed down for tourism activities. There are reports which indicate that a large number of wild animals stay outside these protected areas, and the wildlife density remains comparatively high in the unprotected human-dominated landscape outside some of the old national parks [20]. Such results suggest the need of proper conservation policy, which can address rightfully the conservation of biodiversity and ecosystem while promoting ecotourism. Merely promulgating protected areas is not a viable solution.

The present study of Dhanolti ecopark suggests the need of proper identification of natural sites, either focusing conservation of biodiversity and ecosystem or ecotourism. The keep off zones must be identified properly and demarcated so that some natural wilderness areas are made available for sensitive flora and fauna. At the same time, innovations in ecotourism are also required. To meet this objective, the concerned institutions should develop proper planning and policy for meeting the sustainability of natural resources.

\section{Acknowledgements}

The author thanks the state forest department, and ecopark authorities and staff for sharing their views during the course of this study. I thank Komal Singh, subdivisional officer, and Jyoti Belwal for their support and valuable suggestions. Director, Indian Institute of Forest Management is acknowledged for help and guidance.

\section{References}

[1] Kala CP (2005) Indigenous uses, population density, and conservation of threatened medicinal plants in protected areas of the Indian Himalayas. Conservation Biology, 19 (2): 368-378.

[2] Kala CP, Ratajc P (2012) High altitude biodiversity of the Alps and the Himalayas: ethnobotany, plant distribution and conservation perspective. Biodiversity and Conservation, 21 (4): 1115-1126.

[3] Kala CP (2002) Indigenous knowledge of Bhotiya tribal community on wool dyeing and its present status in the Garhwal Himalaya, India. Current Science, 83 (7): 814-817. 
[4] Kala CP, Farooquee NA (2003) Traditional wisdom, equity and community participation making the commercialization of grasses in Bhyundar Valley, Uttaranchal Himalaya a success. Journal of Human Ecology, 14 (3): 159-163.

[5] Kala CP (2006) Medicinal plants: Potential for economic development in the state of Uttaranchal, India. International Journal of Sustainable Development \& World Ecology, 13 (6): 492-498.

[6] Kala CP (2007) Local preferences of ethnobotanical species in the Indian Himalaya: Implications for environmental conservation. Current Science, 93 (12): 1828-1834.

[7] Kala CP (2012) A delicious affair. Down to Earth, 21 (1): 46-48.

[8] Singh RB, Mal S, Kala CP (2009) Community responses to mountain tourism: A case in Bhyundar Valley, Indian Himalaya. Journal of Mountain Sciences, 6 (4): 394-404.

[9] Kala CP (1998) Ecology and conservation of alpine meadows in the Valley of Flowers National Park, Garhwal Himalaya. Ph.D. Thesis, Forest Research Institute, Dehradun, India. 180 pp.

[10] Kala CP, Maikhuri RK (2011) Mitigating people-park conflicts on resource use through ecotourism: A case of the Nanda Devi Biosphere Reserve, Indian Himalaya. Journal of Mountain Sciences, 8: 87-95.

[11] UN News Centre (2013) UN agency welcomes General Assembly's adoption of resolution on ecotourism. United Nations World Tourism Organizations.

http://www.un.org/apps/news/story.asp?NewsID=43873\&Cr=touri sm\&Cr1\#.UYivSErEFsg
[12] MoEF (2011) GUIDELINES FOR ECOTOURISM IN AND AROUND PROTECTED AREAS, Ministry of Forest and Environment, Govt. of India, New Delhi. http://uttarakhandtourism.gov.in/files/mtig/1.pdf

[13] Kala CP (2004) The Valley of Flowers: Myth and Reality. International Book Distributors, Dehradun, India. 215 pp.

[14] Kala CP (2004) Pastoralism, plant conservation, and conflicts on proliferation of Himalayan Knotweed in high altitude protected areas of the Western Himalaya, India. Biodiversity and Conservation, 13 (5): 985-995.

[15] Kala CP (2010) Status of an indigenous agro-forestry system in changing climate: A case study of the middle Himalayan region of Tehri Garhwal, India. Journal of Forest Science, 56 (8): 373-380.

[16] Kala CP (2010) Medicinal Plants of Uttarakhand: Diversity, Livelihood and Conservation. Biotech Books, Delhi, India. 188 pp.

[17] Kala CP (2011) Medicinal plants used for dermatological disorders: a study of Uttarakhand state in India. Australian Journal of Medical Herbalism, 23 (3): 132-137.

[18] WII (2012) Envis Centre on Wildlife and Protected Areas, Wildlife Institute of India, Dehradun. http://wiienvis.nic.in/.

[19] Bookbinder MP, Dinerstein E, Rijal A, Cauley H, Rajouria A (1998) Ecotourism support's to biodiversity conservation. Conservation Biology, 12 (6): 1399-1404.

[20] Athreya, V, Odden M, Linnell JDC, Krishnaswamy J, Karanth U (2013) Big Cats in Our Backyards: Persistence of Large Carnivores in a Human Dominated Landscape in India. PLoS ONE 8(3): e57872. 